\title{
CASP8 wt Allele
}

National Cancer Institute

\section{Source}

National Cancer Institute. CASP8 wt Allele. NCI Thesaurus. Code C49560.

Human CASP8 wild-type allele is located within 2q33-q34 and is approximately $54 \mathrm{~kb}$ in length. This allele, which encodes caspase- 8 protein, plays a role in apoptosis via the cleavage and activation of caspases 3, 4, 6, 7, 9 and 10. Certain allelic variants of CASP8 are associated with caspase- 8 protein deficiency and somatic hepatocellular carcinoma. 